\title{
Klasifikasi Radang Kandung Kemih dan Nefritis dari Pelvis Ginjal Menggunakan Metode Learning Vector Quantization
}

\author{
Achmad Izaaz \\ Universitas Merdeka Pasuruan, Jl Ir.H.Juanda No 68, Pasuruan \\ E-mail: achmadizaaz@outlook.com
}

\begin{abstract}
Abstrak - Infeksi saluran kemih merupakan suatu infeksi yang disebabkan oleh pertumbuhan mikroorganisme di dalam saluran kemih manusia. Radang kandung kemih dan nerfitis dari pelvis ginjal merupakan salah satu infeksi saluran kemih. Diagnosis Radang kandung kemih dan nerfitis dari pelvis ginjal dapat dilakukan melalui pemeriksaan secara fisik terhadap pasien, riwayat penyakit, pemeriksaan laboratorium, keluarga, serta informasi yang terkait. Tujuan penulisan ini menyajikan hasil kajian mengenai implementasi metode Learning Vector Quantization untuk memudahkan klasifikasi radang kandung kemih dan nefritis dari pelvis ginjal. Hasil penelitian menunjukan bahwa penggunaan metode Learning Vector Quantization dengan parameter learning rate 0.5 , minimal error 0.0001, dan maksimal epoch 2 mendapatkan tingkat akurasi sebesar $86.95652173913 \%$ dari pengujian data training sebanyak 67 dan data testing sebanyak 23. Kesimpulan semakin banyak nilai epoch dan nilai learning rate maka semakin baik hasil yang didapatkan.
\end{abstract}

\section{Kata Kunci-Klasifikasi, LVQ, Infeksi Saluran}

\section{Pendahuluan}

Infeksi saluran kemih merupakan suatu infeksi yang disebabkan oleh pertumbuhan mikroorganisme di dalam saluran kemih manusia. Saluran kemih manusia merupakan organ-organ yang bekerja untuk mengumpul dan menyimpan urin serta organ yang mengeluarkan urin dari tubuh, yaitu ginjal, ureter, kandung kemih dan uretra. Menurut Departemen Kesehatan Republik Indonesia jumlah penderita infeksi saluran kemih di Indonesia masih cukup banyak, mencapai 90-100 kasus per 100.000 penduduk pertahun nya atau sekitar 180.000 kasus baru pertahun [1].

Radang kandung kemih dan nefritis dari pelvis ginjal merupakan salah satu jenis infeksi saluran kemih yang paling sering terjadi. Penyakit ini lebih sering menyerang wanita dibandingkan pria. Hal ini disebabkan oleh ukuran uretra (saluran urine dari kandung kemih ke luar tubuh) yang lebih pendek, dan jarak uretra yang lebih dekat dengan anus [2].

Diagnosis radang kandung kemih dan nerfitis dapat dilakukan melalui pemeriksaan secara fisik terhadap pasien, riwayat penyakit, pemeriksaan laboratorium, keluarga, serta informasi yang terkait. Untuk itu diperlukan pengelompokan jenis penyakit peradangan akut beserta gejala-gejala yang dialami pasien lalu dijadikan sebuah data pembelajaran. Data pembelajaran dijadikan data latih untuk pemetaan ke dalam data uji, sehingga klasifikasi jenis-jenis penyakit yang didapat dari rekam medis disimpan kedalam database kemudian di diproses dengan memanfaatkan perkembangan teknologi informasi untuk menentukan hasil luaran dengan benar.

Pemanfaatan teknologi digunakan untuk mempermudah pekerjaan manusia yang sifatnya memberatkan, seperti halnya perhitungan yang banyak dan berulang-ulang serta membutuhkan banyak waktu dalam pengambilan kesimpulan [3]. Sistem pengambilan kesimpulan telah banyak dilakukan di berbagai bidang ilmu, seperti yang dilakukan oleh [4] implementasi Learning Vector Quantization sebagai alat bantu identifikasi kelainan jantung melalui elektrokardiogram yang memperoleh tingkat akurasi $96 \%$ dari 25 data uji. LVQ juga digunakan oleh [5] dalam mengklasifikasi citra daging sapi dan daging babi mendapatkan tingkat akurasi tertinggi rata-rata sebesar $94,81 \%$.

Berdasarkan beberapa penelitian terdahulu yang pernah menggunakan metode klasifikasi Learning Vector Quantization. Pada penelitian ini, peneliti tertarik untuk meneliti lebih lanjut untuk mengetahui dan mendalami tentang metode Learning Vector Quantization dalam mengklasifikasikan penyakit radang kandung kemih dan nefritis akut secara terkomputerisasi berdasarkan data klinis pasien serta untuk mengetahui tingkat akurasi.

Berdasarkan latar belakang diatas dapat dirumuskan bagaimana algoritma klasifikasi Learning Vector Quantization dapat diterapkan dalam mengklasifikasi radang kandung kemih dan nefritis dari pelvis ginjal

1. Algoritma klasifikasi yang digunakan adalah algoritma Learning Vector Quantization.

2. Atribut yang digunakan dari data berjumlah 6 atribute yaitu suhu tubuh, terjadinya mual, sakit lumbar, dorongan buang air kecil terus-menerus, nyeri mikturisi dan pembakaran uretra, pembengkakan outlet uretra [6].

3. Kelas yang digunakan dari data berjumlah 2 kelas yaitu radang kandung kemih dan nefritis dari pelvis ginjal.

4. Hasil dari output sistem yang akan dibuat ini adalah tingkat persentase akurasi yang didasari input dari atribute data, hasil probabilitas dan prediksi radang kandung kemih dan nefritis dari pelvis ginjal

Tujuan dari penelitian ini adalah untuk menerapkan algoritma Learning Vector Quantization dalam melakukan klasifikasi pada radang kandung kemih dan nefritis dari pelvis ginjal dan memberikan hasil tingkat akurasi. 


\section{BAHAN DAN METODE}

\section{A. Klasifikasi}

Klasifikasi merupakan kata dari bahasa inggris, yaitu "classification" dan kata ini berasal dari kata "to classy" yang berarti menggolongkan dan menempatkan bendabenda di suatu tempat. Terdapat beberapa pendapat tentang definisi klasifikasi menurut para ahli dan dari berbagai sumber:

1. Menurut Sulistyo Basuki (1991), mengatakan bahwa klasifikasi berasal dari kata Latin "classis", klasifikasi adalah proses pengelompokan, artinya mengumpulkan benda/entitas yang sama. Secara umum dapat dikatakan bahwa batasan klasifikasi adalah usaha menata alam pengetahuan ke dalam tata urutan sistematis.

2. Menurut Hamakonda dan Tairas (2002), mengatakan klasifikasi adalah pengelompokkan yang sistematis pada sejumlah objek, gagasan, buku atau benda-benda lain ke dalam kelas atau golongan tertentu berdasarkan ciri-ciri yang sama

\section{B. Learning Vector Quantization}

Learning Vector Quantization adalah salah satu metode untuk klasifikasi yang pertama kali diperkenalkan oleh Tuevo Kohonen yang memperkenalkan Self-Organizing Feature Map juga, Learning Vector Quantization merupkan jaringan hybrid yang menggunakan supervised dan unsupervised learning. Metode LVQ telah digunakan oleh banyak peneliti untuk memecahkan masalah klasifikasi. Learning Vector Quantization merupakan sebuah metode pola klasifikasi pada setiap unit output mewakili sebuah kelas tertentu. Vektor bobot dari sebuah unit output digunakan sebagai vektor referensi untuk sebuah unit yang diwakili oleh sebuah kelas.

Learning Vector Quantization adalah suatu metode untuk melakukan pembelajaran pada lapisan kompetitif yang terawasi. Suatu lapisan kompetitif akan secara otomatis belajar untuk mengklasifikasikan vektor-vektor input. Kelas-kelas yang didapatkan sebagai hasil dari lapisan kompetitif ini hanya tergantung pada jarak antara vektorvektor input. Jika terdapat 2 vektor input mendekati sama, maka lapisan kompetitif akan meletakkan kedua vektor input tersebut ke dalam kelas yang sama. Arsitektur jaringan LVQ adalah sebagai berikut [3].

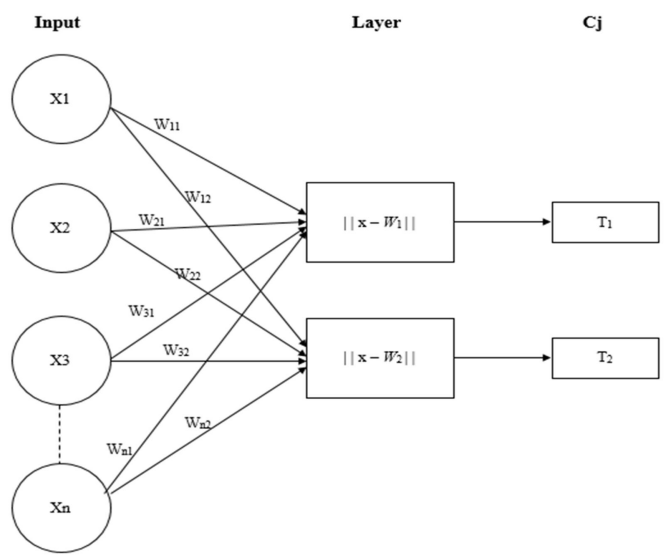

Gambar 1. Arsitektur Jaringan Learning Vector Quantization ISSN 2615-5788 Print (2615-7764) JURNAL TEKNIK ELEKTRO DAN KOMPUTER TRIAC https://journal.trunojoyo.ac.id/triac
Keterangan:

1. $\mathrm{X}_{1}, \mathrm{X}_{2}, \mathrm{X}_{3}, \ldots, \mathrm{Xn}$ merupakan vektor inputan. Kemudian vektor-vektor input tersebut dihubungkan ke vektor $\mathrm{W}_{1}$ dan $\mathrm{W}_{2}$.

2. $\mathrm{W}_{1}$ dan $\mathrm{W}_{2}$ merupakan vektor bobot pertama dan kedua. $\mathrm{W}_{1}$ merupakan vektor bobot yang menghubungkan setiap neuron pada lapisan input ke neuron pertama pada lapisan output, sedangkan $\mathrm{W}_{2}$ merupakan vektor bobot yang menghubungkan setiap neuron pada lapisan input ke neuron yang kedua pada lapisan output

3. $\mathrm{T}_{1}$, dan $\mathrm{T}_{2}$ merupakan fungsi aktivasi pertama dan kedua. Fungsi aktivasi F1 akan memetakan y_in1 ke $\mathrm{y} 1=1$ apabila $\left\|\mathrm{X}-\mathrm{W}_{1}\right\|<\left\|\mathrm{X}-\mathrm{W}_{2}\right\|$, dan $\mathrm{y} 1=0$ jika sebaliknya. Demikian pula dengan yang terjadi pada fungsi aktivasi T2.

4. $\mathrm{T}_{1}$ dan $\mathrm{T}_{2}$ merupakan output target pertama dan kedua.

Adapun kelebihan dari LVQ sebagai berikut:

1. Nilai error yang dihasilkan lebih kecil.

2. Data set yang besar dapat diringkas menjadi vektor kecil pada tahap klasifikasi.

3. Tidak ada pembatasan pada dimensi codebook.

4. Model yang dihasilkan dapat dilakukan perbaharuan secara bertahap

Sedangkan kelemahan dari LVQ sebagai berikut:

1. Diperlukan perhitungan yang akurat terhadap jarak untuk seluruh atribut.

2. Akurasi model Learning Vector Quantization bergantung pada inisialisasi dan parameter yang digunakan untuk perhitungan.

3. Distribusi kelas pada data training mempengaruhi nilai akurasi.

4. Sulitnya jumlah vektor yang ditentukan pada masalah yang diberikan.

Pada sistem pembelajaran Learning Vector Quantization terdapat ketentuan dasar teori LVQ. Parameter yang dibutuhkan diantaranya adalah:

TABLE I. PARAMETER LEARNING QUNATIZATION VECTOR

\begin{tabular}{|c|c|l|}
\hline No & Parameter & Keterangan \\
\hline 1 & $\mathrm{X}$ & Vektor-vektor inputan pelatihan \\
\hline 2 & $\mathrm{~T}$ & $\begin{array}{l}\text { Target, kelas atau kategori yang benar } \\
\text { untuk vektor pelatihan }\end{array}$ \\
\hline 3 & $\mathrm{~W}_{\mathrm{j}}$ & $\begin{array}{l}\text { Vektor bobot tiap unit keluaran ke-j } \\
\left(\mathrm{W} 1_{\mathrm{j}}, \mathrm{W} 2_{\mathrm{j}}, \ldots, \mathrm{Wn}_{\mathrm{j}}\right)\end{array}$ \\
\hline 4 & $\begin{array}{c}\text { Learning } \\
\text { rate }(\alpha)\end{array}$ & Nilai tingkat pelatihan / pembelajaran \\
\hline 5 & Dec $(\alpha)$ & Pengurangan learning rate \\
\hline 6 & Min $(\alpha)$ & $\begin{array}{l}\text { Minimal tingkat pelatihan yang masih } \\
\text { diperbolehkan }\end{array}$ \\
\hline 7 & $\begin{array}{c}\text { Maks } \\
\text { Epoch }\end{array}$ & $\begin{array}{l}\text { Jumlah iterasi maksimal yang } \\
\text { dibolehkan selama proses pelatihan }\end{array}$ \\
\hline
\end{tabular}

Dibawah ini adalah algoritma dari metode Learning Vector Quantization:

1. Inisialisasi learning rate $(\alpha)$, maks epoch, dan min Error.
Vol 8 No. 2
(a) Achmad Izaaz 
2. apabila kondisi false, lakukan langkah 2 sampai 6

3. Untuk setiap input pelatihan vektor $\mathrm{x}$ lakukan langkah $4-5$

4. Temukan ${ }_{\mathrm{j}}$ hingga $\left\|x-w_{j}\right\|$ minimum $\square \square \square(1)$

5. Perbaharui nilai $w_{j}$ sebagai berikut:

a. Jika $T=C_{j}$, maka

$W_{j(\text { baru })}=W_{j(\text { lama })}+\alpha\left\|x-W_{j(\text { lama })}\right\| \square$

b. Jika $T \neq C_{j}$, maka

$W_{j(\text { baru })}=W_{j(\text { lama })}-\alpha\left\|x-W_{j(\text { lama })}\right\|$

6. Kurangi nilai learning rate $(\alpha)$.

7. Apabila kondisi berhenti: yaitu kondisi iterasi sudah mencapai nilai maksimal epoch yang telah ditentukan atau nilai learning rate $(\alpha)$ mencapai nilai min Error.

Setelah proses pembelajaran Learning Vector Quantization selesai maka langkah selanjutnya adalah proses pengambilan hasil output LVQ. Pengambilan hasil dilakukan hanya pada proses penngujian. Pada dasarnya, tahapan ini hanya memasukkan input nilai bobot terbaik (akhir) kemudian mencari jarak terdekat dengan perhitungan Euclidian. Dan sistem ini dibangun dengan skema seperti pada gambar dibawah ini.

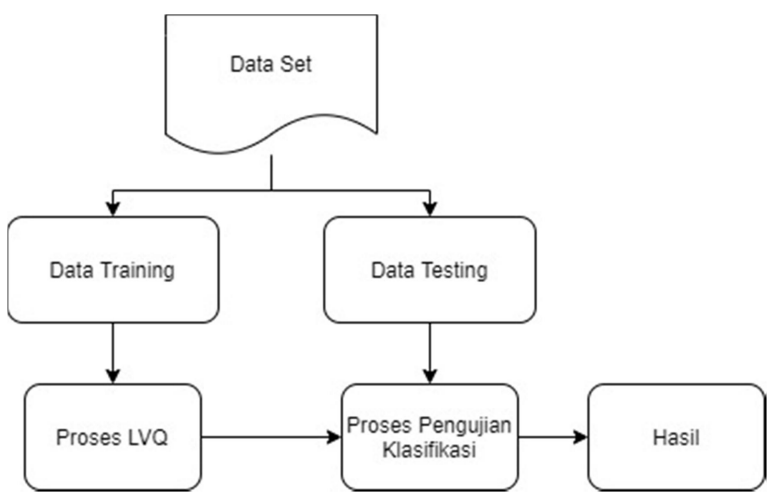

Gambar 2. Diagram Pengolahan Data

\section{Dataset}

Dataset adalah kumpulan data yang ada dalam basis data. Sesuai kebutuhan sistem, data dibagi menjadi dua untuk pembalajaran (training) yang nantinya dibandingkan dengan data ujicoba untuk mengetahui kinerja Learning Vector Quantization dalam klasifikasi penyakit radang kandung kemih dan nefritis dari pelvis ginjal. Data yang digunakan untuk training sebanyak 67 data, sedangkan untuk ujicoba 23 data. Data ujicoba harus benar-benar berbeda dari data pembelajaran untuk memenuhi aspek objektivitas. Fitur yang digunakan pada diagnosis penyakit radang kandung kemih dan nefritis dari pelvis ginjal selengkapnya ditunjukkan pada tabel dibawah ini.

TABLE II. DAFTAR FITUR DAN NILAI SATUAN

\begin{tabular}{|c|l|l|}
\hline No & Variable & Nilai \\
\hline 1 & Suhu tubuh & Numeric \\
\hline 2 & Mual & $(0)$ Tidak, (1) Ya \\
\hline 3 & Sakit lumbar / punggung & $(0)$ Tidak, (1) Ya \\
\hline 4 & $\begin{array}{l}\text { Dorongan buang kecil terus- } \\
\text { menerus }\end{array}$ & (0) Tidak, (1) Ya \\
\hline
\end{tabular}

ISSN 2615-5788 Print (2615-7764)

JURNAL TEKNIK ELEKTRO DAN KOMPUTER TRIAC

https://journal.trunojoyo.ac.id/triac 2021

\begin{tabular}{|c|l|c|}
\hline 5 & Nyeri mekturisi & (0) Tidak, (1) Ya \\
\hline 6 & $\begin{array}{l}\text { Pembakaran uretra, gatal, } \\
\text { pembengkakan outlet uretra }\end{array}$ & (0) Tidak, (1) Ya \\
\hline
\end{tabular}

\section{Hasil dan Pembahasan}

Dalam aplikasi ini dibangun dengan menggunakan bahasa pemrograman PHP. Proses aplikasi yang telah dibangun memiliki beberapa proses yaitu (1) input data training dan testing (2) menentukan nilai bobot awal (3) proses pembelajaran dengan algoritma learning vector quantization.

\section{A. Halaman Data Training}

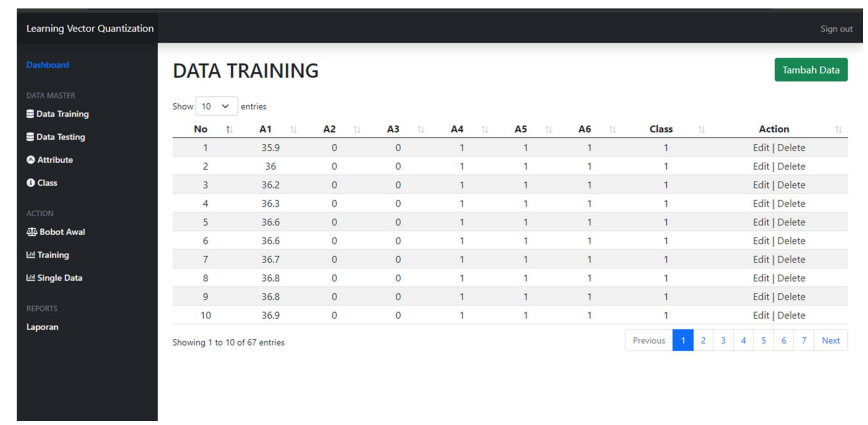

Gambar 3. Halaman Data Training

Pada gambar 3 merupakan halaman data training, pengguna dapat mengelola data training meliputi: menambahkan, mengubah dan menghapus data training.

\section{B. Halaman Data Testing}

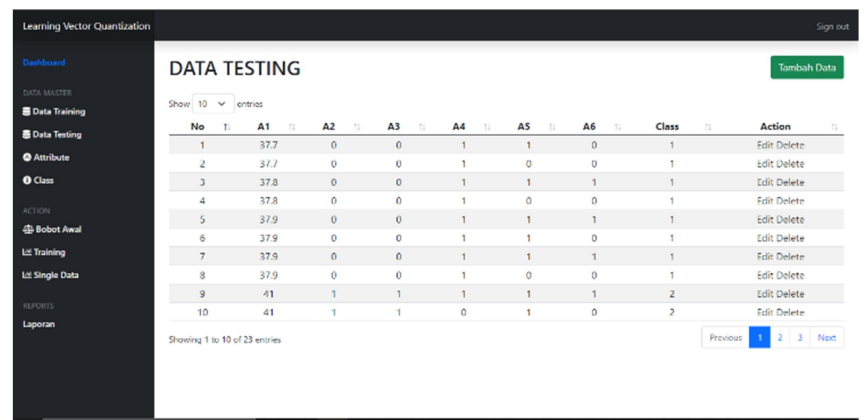

Gambar 4. Halaman Data Testing

Pada gambar 4 merupakan halaman data testing, pengguna dapat mengelola data testing meliputi: menambahkan, mengubah dan menghapus data testing.

\section{Halaman Bobot Awal}

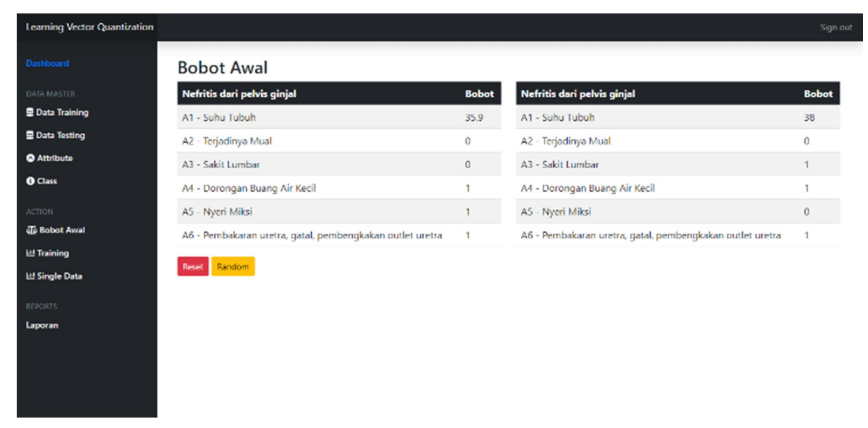

Gambar 5. Halaman Bobot Awal

Pada gambar 5 merupakan halaman bobot awal, pengguna dapat menentukan bobot awal secara default Vol 8 No.2@ @ Achmad Izaaz 
maupun acak yang diambil dari data training berdasarkan tiap kelasnya.

\section{Halaman Training}

Sebelum melakukan proses learning vector quantization, pengguna harus menginisialisasi parameter terlebih dulu, meliputi: meliputi nilai maksimum epoch yang digunakan untuk menghentikan program apabila menghasilkan nilai luaran yang sama, serta learning rate ( $\alpha)$ yang menggambarkan laju pembelajaran. Semakin besar $\alpha$, semakin besar laju pembelajaran. Decrement $\alpha$ merupakan besaran nilai yang digunakan untuk mengurangi nilai learning rate $(\alpha)$ agar mendekati bobot ideal. Min $(\alpha)$ adalah nilai terkecil dari learning rate $(\alpha)$ yang diinginkan.

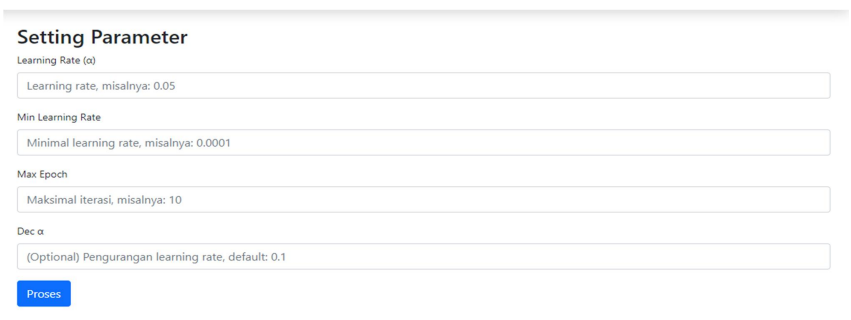

Gambar 6. Setting Parameter

Pada gambar 6 merupakan halaman untuk mengatur paramater yang akan digunakan dalam proses training dan testing. Ketika tombol di submit maka akan dilanjutkan ke proses perhitungan algoritma learning vector quantization.

Hasil dari proses perhitungan ini, mendapatkan nilai bobot terbaik dari pembelajaran pada data training dengan menggunakan metode learining quantization vector.

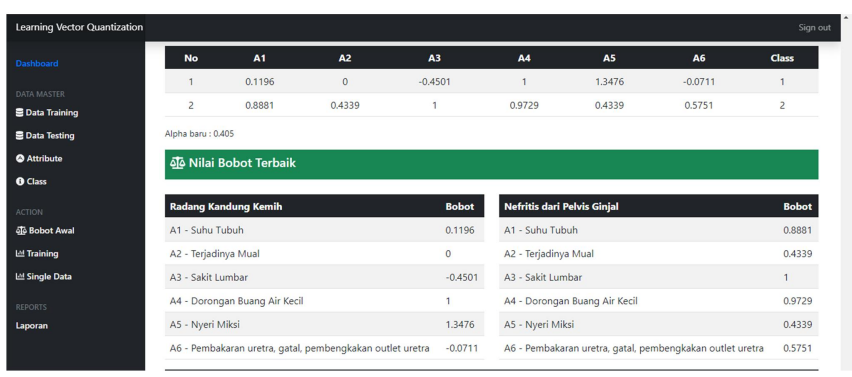

Gambar 7. Nilai Bobot Terbaik

Nilai bobot bisa bernilai minus dikarenakan pada waktu pembelajaran data training terdapat data yang hasilnya tidak sesuai dengan target data, sehingga dilakukan pembaruan bobot menggunakan rumus (3).

Setelah mendapatkan nilai bobot terbaik, selanjutnya dapat dilakukan ujicoba multi data dimaksudkan untuk mempermudah pengujian dengan menggunakan banyak data masukan sekaligus, yang pada penelitian ini dilakukan dengan menggunakan data uji sebanyak 23 data, yang hasilnya dibandingkan dengan target data pembelajaran untuk mengetahui tingkat akurasi implementasi metode Learning Vector Quantization. Presentase tingkat kebenaran hasil dapat diperoleh dengan menggunakan persamaan:

Akurasi : $\left(\frac{\text { Jumlah has sesuai }}{\text { Jumlah keseluruha data }}\right) \times 100$

Dari 23 data testing, terdapat 20 data yang mendapatkan hasil perhitungan yang sesuai target datanya, dan terdapat 3 data yang tidak sesuai targetnya. Sehingga dalam penerapan

metode learning vector quantization pada klasifikasi radang kandung kemih dan nefritis dari pelvis ginjal mendapatkan tingkat akurasi sebesar 86.95652173913\%. Sebagaimana ditunjukkan pada Gambar 7
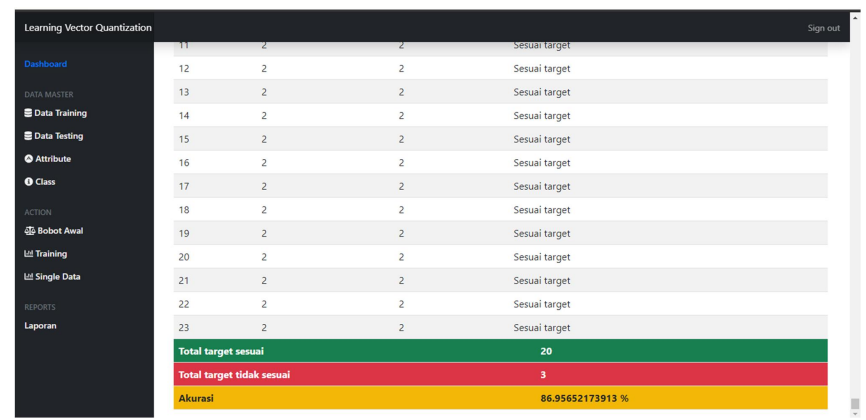

Gambar 7. Hasil Akurasi

\section{KESIMPULAN}

Berdasarkan hasil dari penelitian dengan metode Learning vector quantiation pada klasifikasi radang kandung kemih dan nefritis dari pelvis ginjal dapat disimpulkan bahwa:

1. Implementasi metode Learning vector quantization pada sistem klasifikasi radang kandung kemih dan nefritis dari pelvis ginjal

2. Akurasi yang didapatkan dari pelatihan dengan 67 data training dan 23 data testing mendapatkan tingkat akurasi 86. 95652173913\% dengan parameter learning rate sebesar 0.5, maksimal epoch sebanyak 2, minimal error sebesar 0.0001 dan dec $\alpha$ sebesar 0.1 .

Sistem klasifikasi radang kandung dan nefritis dari pelvis ginjal dengan metode learning vector quantization masih memiliki kekurangan yang harus diperbaiki sehingga diharapkan adanya pengembangan lebih lanjut. Saran yang dapat digunakan sebagai acuan untuk pengembangan selanjutnya adalah sistem ini hanya mampu mengklasifikasi 2 penyakit yaitu: radang kandung kemih dan nefritis dari pelvis ginjal. Sistem masih dapat dikembangkan agar mampu melakukan klasifikasi penyakit yang lebih banyak lagi.

\section{DAFTAR PUSTAKa}

[1] R. Depkes, "Survei Demografi dan Kesehatan Indonesia," Depkes RI, Jakarta, 2014.

[2] "Infeksi Kandung Kemih," 1402 2020. [Online]. Available: https://www.alodokter.com/infeksi-kandung-kemih.

[3] S. Kusumadewi, Artificial Intellegence Tehnik dan Aplikasinya, Yogyakarta: Graha Ilmu, 2003.

[4] F. Karimah, "Implementasi Learning Vector Quantization (LVQ) sebagai Alat Bantu Identifikasi Kelainan Jantung Melalui Citra Elektrokardiogram," Jurnal Sains dan Teknologi, 2012.

[5] M. S. C. L. H. E. B. Jasril, "Implementasi Learning Vektor Quantization (LVQ) Dalam Mengidentifikasi Citra Daging Babi Dan Daging Sapi," Seminar Nasional Teknologi Informasi, Komunikasi dan Industri, 2015.

[6] J. Czerniak and H. Zarzycki, "Application of rough sets in the presumptive diagnosis of urinary system diseases," Artifical Inteligence and Security in Computing System, pp. 41-51, 2003.

[7] B. Sulistyo, Pengantar Ilmu Perpustakaan, Jakarta: Gramedia Pustaka Utama, 1991

[8] Hamakonda and T. , Pengantar Klasifikasi Persepuluhan Dewey, Jakarta: BPK Gunung Mulya, 2002.

\section{(a) Achmad Izaaz}

